\title{
FABRICATION INFLUENCE ON THE SURFACE MORPHOLOGY AND STRUCTURE OF VAPOUR ETCHED POROUS SILICON
}

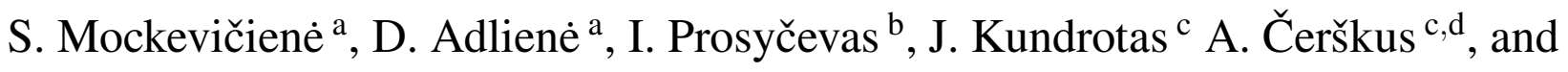 \\ A. Baltušnikas \\ a Physics Department, Kaunas University of Technology, Studentu 50, LT-51368 Kaunas, Lithuania \\ E-mail: skirmante.mockeviciene@ktu.lt \\ ${ }^{\mathrm{b}}$ Institute of Materials Science, Kaunas University of Technology, Savanoriu 271, LT-50131, Kaunas, Lithuania \\ ${ }^{\mathrm{c}}$ Semiconductor Physics Institute, Center for Physical Sciences and Technology, A. Goštauto 11, LT-01108 Vilnius, Lithuania \\ ${ }^{\mathrm{d}}$ Vilnius Pedagogical University, Studentu 39, LT-08106 Vilnius, Lithuania \\ ${ }^{\mathrm{e}}$ Lithuanian Energy Institute, Breslaujos 3, LT-44403 Kaunas, Lithuania
}

Received 10 March 2011; revised 5 June 2011; accepted 21 September 2011

\begin{abstract}
The structure and properties of porous silicon produced applying vapour phase chemical etching of $\mathrm{Si}$ in the mixture of $\mathrm{HF} / \mathrm{HNO}_{3}$ acids are analysed. Experimental layers of different porosity with pores of different sizes and shapes corresponding to different active surface areas were formed by varying the etching parameters. The fabricated structures were investigated using the X-ray diffractometry (XRD), Raman spectroscopy (RS), infrared spectroscopy (FTIR), and photoluminescence spectrometry (PL) methods. SEM imaging was used for the visualization of the produced structures. The refractive index of the experimental layers was evaluated by optical ellipsometry measurements and used for layer porosity estimation. The crystallite size in the fabricated porous structures was estimated taking into account the presence of porous (p-Si), crystalline (c-Si), and amorphous (a-Si) structures in the experimental layers. The size of crystallites in the porous Si layers was found to vary from 3.1 to $4.3 \mathrm{~nm}$, and layer porosity varied from 61.4 to $86.7 \%$ in different samples.

Fabrication of mesoporous silicon structures containing nanosized crystallytes, achieved by controlling the vapour phase chemical etching parameters, is discussed on the basis of the obtained results.
\end{abstract}

Keywords: vapour phase etching, porous $\mathrm{Si}$, nanocrystalline, mesoporous structure

PACS: 61.43.Gt, 61.80.Fe

\section{Introduction}

Porous silicon in various geometries and morphologies can be used for novel optical elements by combining theoretical insights with a suitable porous structure depending on the technological parameters of fabrication methods and some pre- and post-processing of the silicon. Usually, porous silicon is produced by electrochemical etching of Si target; however, in some cases a chemical etching of $\mathrm{Si}$ in the vapour phase of $\mathrm{HF} / \mathrm{HNO}_{3}$ acid mixture is applied for the fabrication of unique porous silicon structures with a characteristic morphology [1-8]. Applying vapour phase chemical etching of $\mathrm{Si}$ it is possible to produce mesoporous and nanoporous silicon structures with embedded nanoclusters containing luminescent dot-like Si particles or to enhance the active surface area. The morphology and luminescence of nanoporous $\mathrm{Si}$ are dependent on the bulk properties (especially Si doping) and technological parameters of etching. The formation mechanism of porous structure in general is explained, but there are still some details remaining, such as the impact of fabrication parameters on the properties of nanoporous structures, which require further investigation.

The aim of the present work was to produce different porous silicon layers on silicon substrate, using the simple vapour phase chemical etching method and to investigate the influence of technological parameters on the structure formation, morphology and, luminescence properties of the fabricated porous silicon structures.

\section{Instruments and methods}

One-side polished p-type silicon (111) samples were used as a target for the production of a porous silicon skeleton. Samples with a contact surface area of ap- 


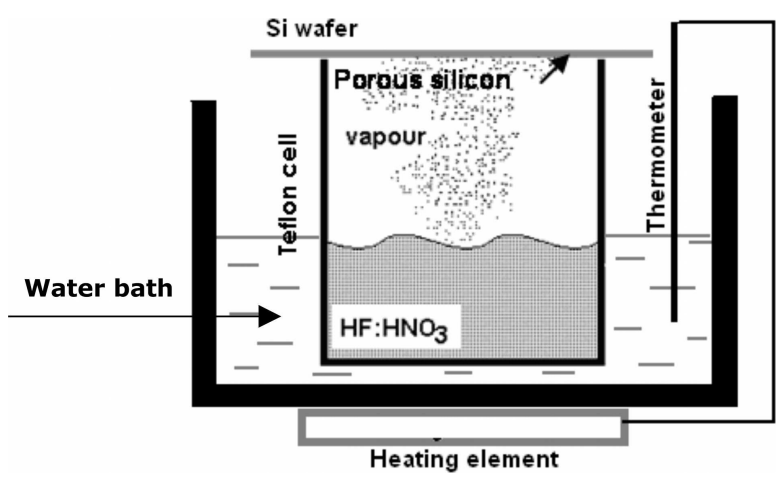

Fig. 1. Experimental set-up for the chemical etching of Si in vapour phase of $\mathrm{HF} / \mathrm{HNO}_{3}$ acid mixture.

proximately $1 \mathrm{~cm}^{2}$ (smaller than the total $\mathrm{Si}$ wafer area) were placed on the top of a Teflon cell at a distance of $10 \mathrm{~mm}$ from the surface of a liquid mixture of the acids $\mathrm{HF}$ and $\mathrm{HNO}_{3}$. Chemical etching was performed in the vapour phase of the acid mixture at a temperature of $20^{\circ} \mathrm{C}$. In order to keep the same temperature of acids during the lengthy etching process, the Teflon cell was dipped into a water bath equipped with a Pt thermometer connected through the regulator to a heating element as shown in Fig. 1.

Two series of porous silicon samples were produced: (i) at varying concentrations of acids in the $\mathrm{HF} / \mathrm{HNO}_{3}$ mixture $(1: 1 ; 1: 2$, and $1: 6)$ and keeping the same etching time of $24 \mathrm{~h}$, and (ii) keeping the concentration of $\mathrm{HF} / \mathrm{HNO}_{3}$ constant (4:1) and changing the etching time $(24,48$, and $60 \mathrm{~h})$. The main fabrication parameters and some initial characteristics of the experimental structures are provided in Table 1 .

A quick visual test to ensure that porous $\mathrm{Si}$ structures had been produced was performed by irradiating experimental samples with a UV lamp (wavelength $254 \mathrm{~nm}$ ) in a Min UVIS Desaga spectrometer. All experimental samples were highly luminescent indicating typical porous Si structures. A porous structure of the experimental samples was visible in the images obtained using a FEI QUANTA 200FEG scanning electron microscope (SEM).
Assuming that a porous Si layer is thicker than the depth of the individual pores, layer thickness was evaluated using an MII-4 interference microscope. Due to the inhomogeneity of the fabricated layers the height of the interference step corresponding to the layer thickness was measured several times in different positions. Bruggeman's model was applied for the calculation of sample porosity [9]:

$$
P=1-\left[\frac{\left(1-n_{\mathrm{PS}}^{2}\right)\left(n_{\mathrm{Si}}^{2}+2 n_{\mathrm{PS}}^{2}\right)}{3 n_{\mathrm{PS}}^{2}\left(1-n_{\mathrm{Si}}^{2}\right)}\right] \cdot 100 \%
$$

where $n_{\mathrm{Si}}$ is the refractive index of silicon and $n_{\mathrm{PS}}$ is the refractive index of a porous Si layer evaluated from ellipsometric measurements using a Gaertner $L 117$ laser ellipsometer operating with a $\mathrm{He}-\mathrm{Ne}$ laser (excitation wavelength $632.8 \mathrm{~nm}$ ).

The chemical bonding structure of porous Si layers was analysed using a Raman scattering spectrometer (Jobin Yvon System) and an FTIR spectrometer (Nicolet 5700, equipped with a 10-degree Specular Reflectance Accessory). The crystalline structure of the produced porous Si layers was analysed and the size of crystallites was estimated from XRD spectra obtained using a DRON-6 X-ray diffractometer operating at $35 \mathrm{kV}$ and $20 \mathrm{~mA}$ and equipped with a single crystal graphite flat monochromator for transmitting only a narrow $\mathrm{Cu} \mathrm{K}_{\alpha}$ wavelength $(\lambda=0.15405 \mathrm{~nm})$. Diffraction patterns were recorded in a scanning mode with $0.02^{\circ}$ steps of $2 \theta$ and the counting time of 0.5 s per step. Qualitative phase identification was performed using the PDF2 data base. Raman spectra were used to estimate crystallite size as well. A permanent Ar laser ILA 120 beam (wavelength $488 \mathrm{~nm}$, incidence angle $45^{\circ}$, beam modulation frequency $130 \mathrm{~Hz}$, maximum excitation power $100 \mathrm{~mW}$ ) was used for photoluminescence (PL) excitation in experimental samples at different temperatures. The photoluminescence of samples was detected with a GaAs detector supported with a photomultiplier FEU157 and analysed in an MDP12 monochromator. Pho-

Table 1. Main fabrication parameters and characteristics of experimental porous silicon structures.

\begin{tabular}{ccccccc}
\hline Series & Samples & $\mathrm{HF} / \mathrm{HNO}_{3}$ & $\begin{array}{c}\text { Etching } \\
\text { time, h }\end{array}$ & $\begin{array}{c}\text { Porous layer } \\
\text { thickness, mm }\end{array}$ & $\begin{array}{c}\text { Refractive } \\
\text { index }\end{array}$ & $\begin{array}{c}\text { Porosity, } \\
\%\end{array}$ \\
\hline \multirow{4}{*}{ I } & $N 11$ & $1: 6$ & 24 & 4.201 & 1.21 & 83.6 \\
& $N 10$ & $1: 2$ & 24 & 2.767 & 1.32 & 75.3 \\
& $N 8$ & $1: 1$ & 24 & 2.103 & 1.50 & 61.4 \\
\hline \multirow{2}{*}{ II } & $N 5$ & $4: 1$ & 24 & 2.013 & 1.43 & 66.8 \\
& $N 20$ & $4: 1$ & 48 & 3.934 & 1.21 & 83.6 \\
& $N 4$ & $4: 1$ & 60 & 4.851 & 1.17 & 86.7 \\
\hline
\end{tabular}




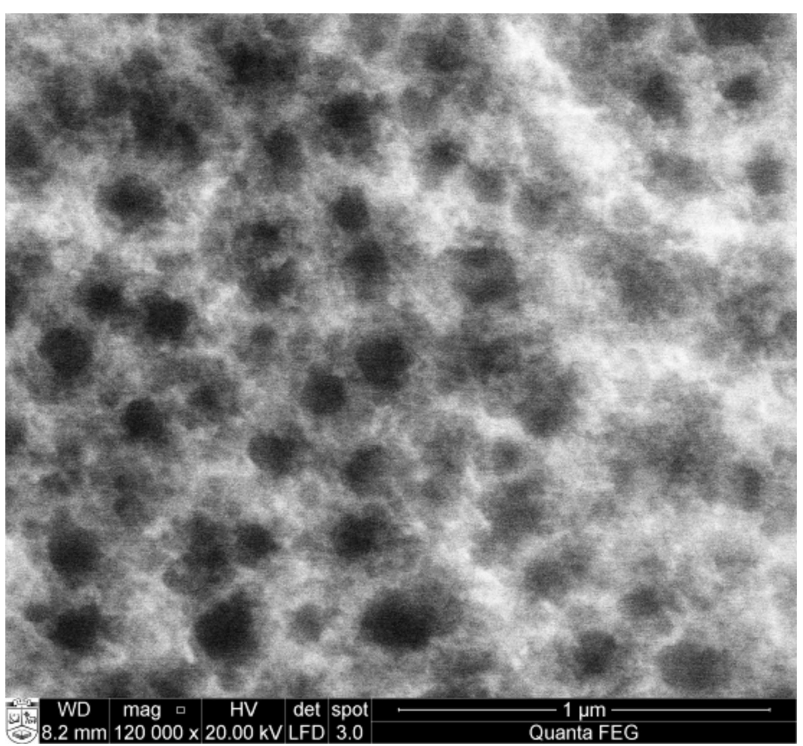

(a)

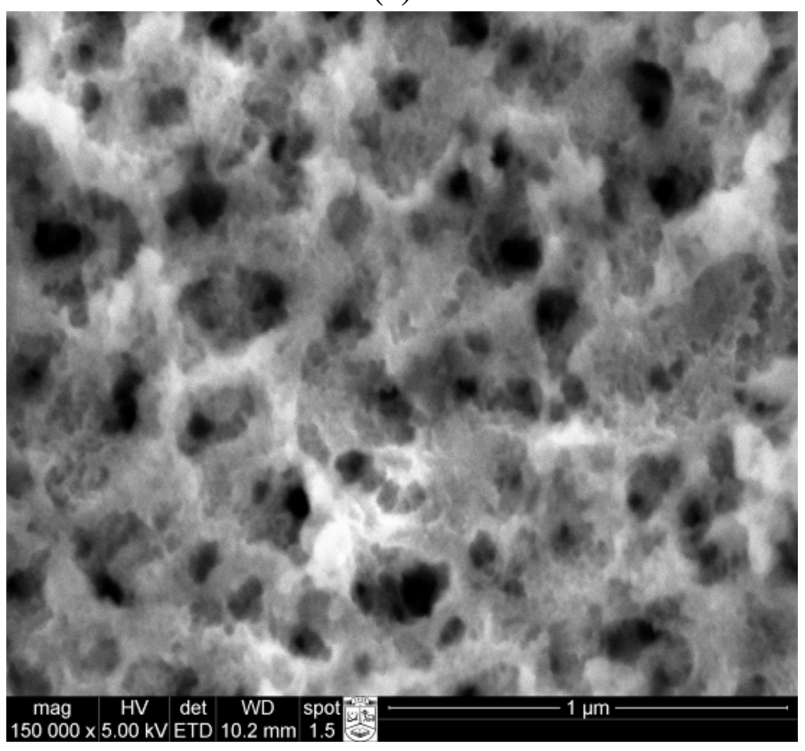

(c)

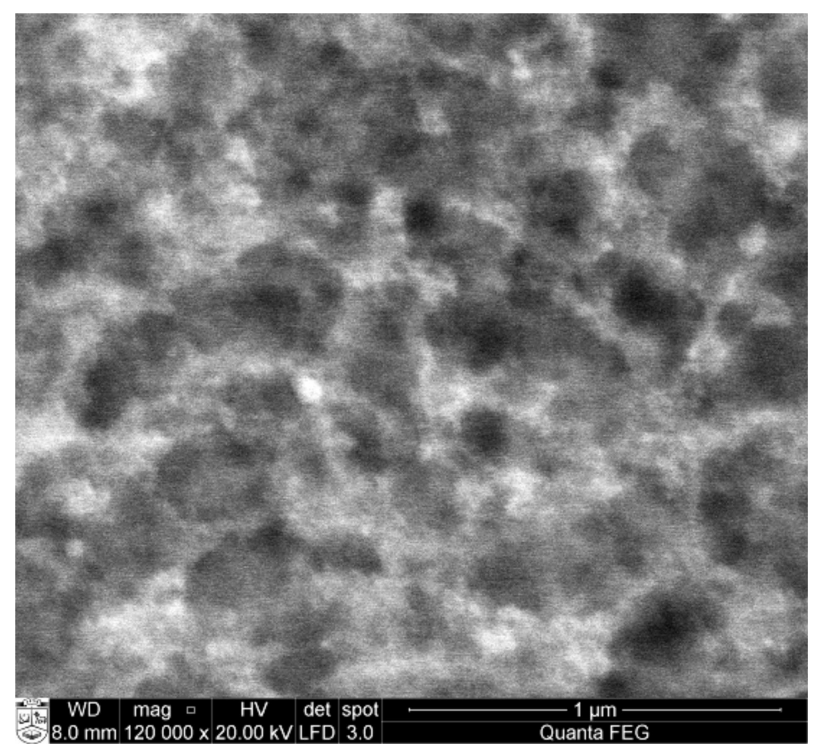

(b)

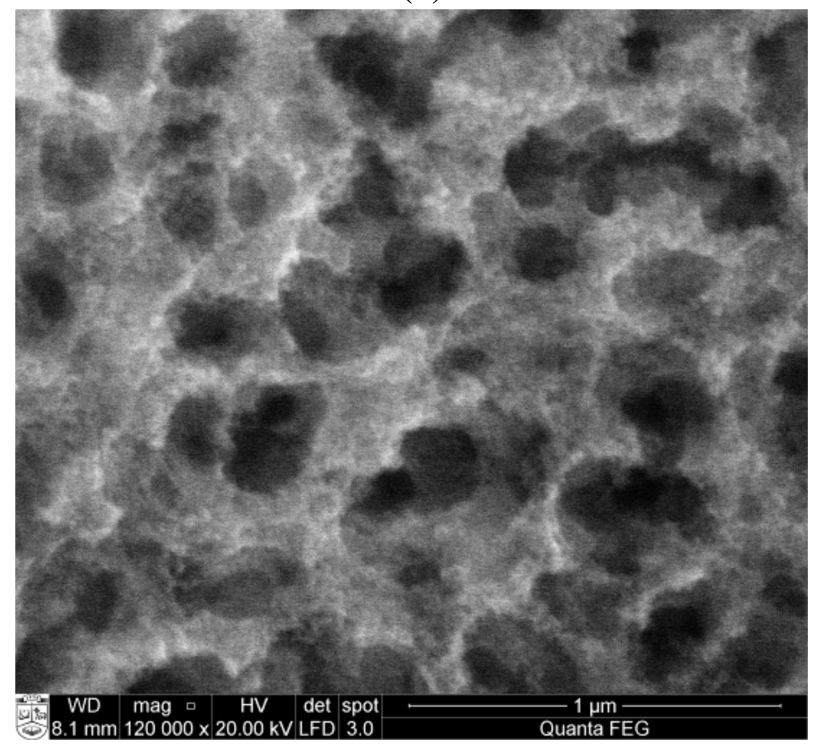

(d)

Fig. 2. SEM images (top view) of fabricated porous Si layers: (a) sample N11 (magn. $\times 120000)$; (b) sample N5 (magn. $\times 120000)$; (c) sample N20 (magn. $\times 150000)$; (d) sample $N 4$ (magn. $\times 120000)$.

toluminescence spectra were used for the evaluation of porous Si structures.

\section{Results and discussion}

Porous silicon structures with pores of different sizes and shapes were produced varying the vapour phase chemical etching process parameters. A certain correlation was found between the thickness and porosity of the experimental layers and relative acid concentrations in a mixture. A higher $\mathrm{HNO}_{3}$ concentration in a mixture during the same etching time corresponded to the formation of thinner porous Si layers with a lower poros- ity (Table 1). A higher HF concentration in a mixture of acids led to a lower porosity of layers if the sample etching time remained the same, as could be seen from SEM images of sample N11 (Fig. 2(a)) and sample N5 (Fig. 2((b)) as well as from the calculated values of porosity presented in Table 1 . Keeping the same ratio $4: 1$ of the $\mathrm{HF} / \mathrm{HNO}_{3}$ acids in a mixture and increasing the etching time, thicker porous Si layers of a higher porosity and a larger active surface area were produced (samples N2O, N4 in Fig. 2). These samples were characterized by pores of different size and shape non-uniformly distributed within a porous layer. The same $83.6 \%$ porosity was found in samples $N 11$ (Fig. 2(a)) and N2O (Fig. 2(c)) produced under differ- 


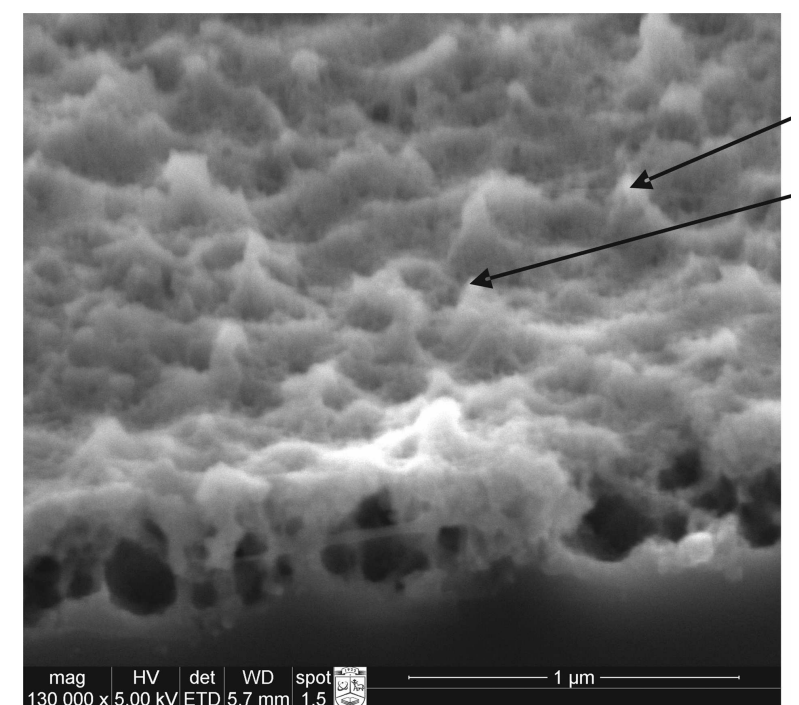

Fig. 3. SEM image of a sample $N 20$ (tilted by $45^{\circ}$, magn. $\left.\times 130000\right)$ with indicated pyramidal texture.

ent etching conditions. This was possibly due to the inhomogeneity of porous layers containing a variety of randomly distributed pores.

As a result of anisotropic etching, the interface be-
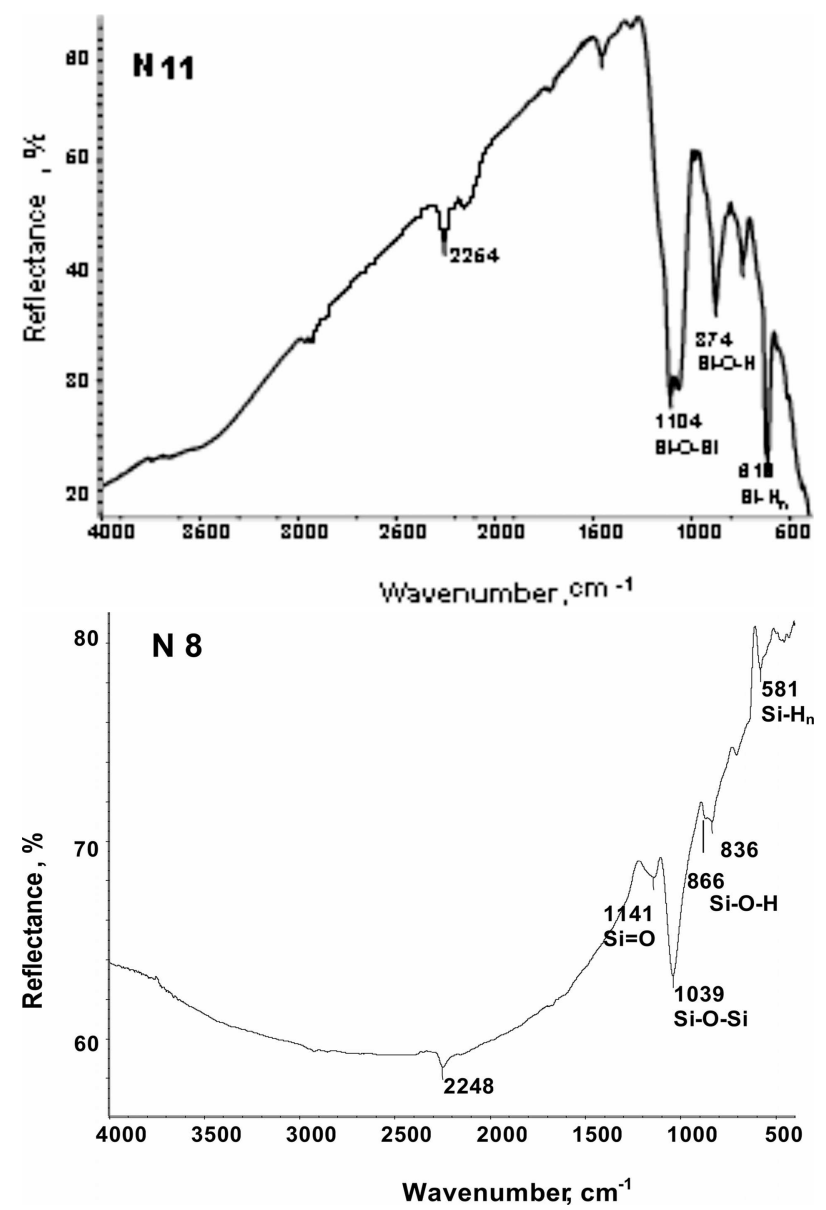

tween the Si substrate and the porous layer was quite rough and formation of a pyramidal structure was observed in SEM images (Fig. 3).

The bonding structure in porous Si layers depended on the etching conditions - $\mathrm{HF}$ content in the $\mathrm{HF} / \mathrm{HNO}_{3}$ acid mixture as well as the etching time and on the pore growth mechanisms [4, 5]. It was analysed using the results of IR spectroscopy. Peaks corresponding to $\mathrm{Si}-$ $\mathrm{H}$ bending (2248-2250 $\left.\mathrm{cm}^{-1}\right), \mathrm{Si}-\mathrm{H}_{n}$ bending (578$\left.638 \mathrm{~cm}^{-1}\right)$, Si-O-Si asymmetric stretching (1029$\left.1104 \mathrm{~cm}^{-1}\right), \mathrm{Si}=\mathrm{O}$ stretching $\left(1137-1151 \mathrm{~cm}^{-1}\right)$, and a doublet of Si-O-H bending $\left(880\right.$ and $\left.840 \mathrm{~cm}^{-1}\right)$ bonds that are usually observed in the porous silicon structure were present in all samples. The relative intensity of competing $\mathrm{Si}-\mathrm{O}-\mathrm{Si}$ and $\mathrm{Si}-\mathrm{H}_{n}$ peaks was decreasing with increasing the etching time (Fig. 4, samples N5 and N4) due to the etching of inner surfaces in porous silicon structures. Formation of $\mathrm{Si}-\mathrm{O}-\mathrm{Si}$ and $\mathrm{Si}-\mathrm{H}_{n}$ bonds in the etched samples depends on the ratio of $\mathrm{HF} / \mathrm{HNO}_{3}$ acids as well. The highest intensities were found in samples N1I (Fig. 4) etched at the lowest HF content in a mixture $\left(\mathrm{HF}: \mathrm{HNO}_{3}=1: 6\right)$, corresponding
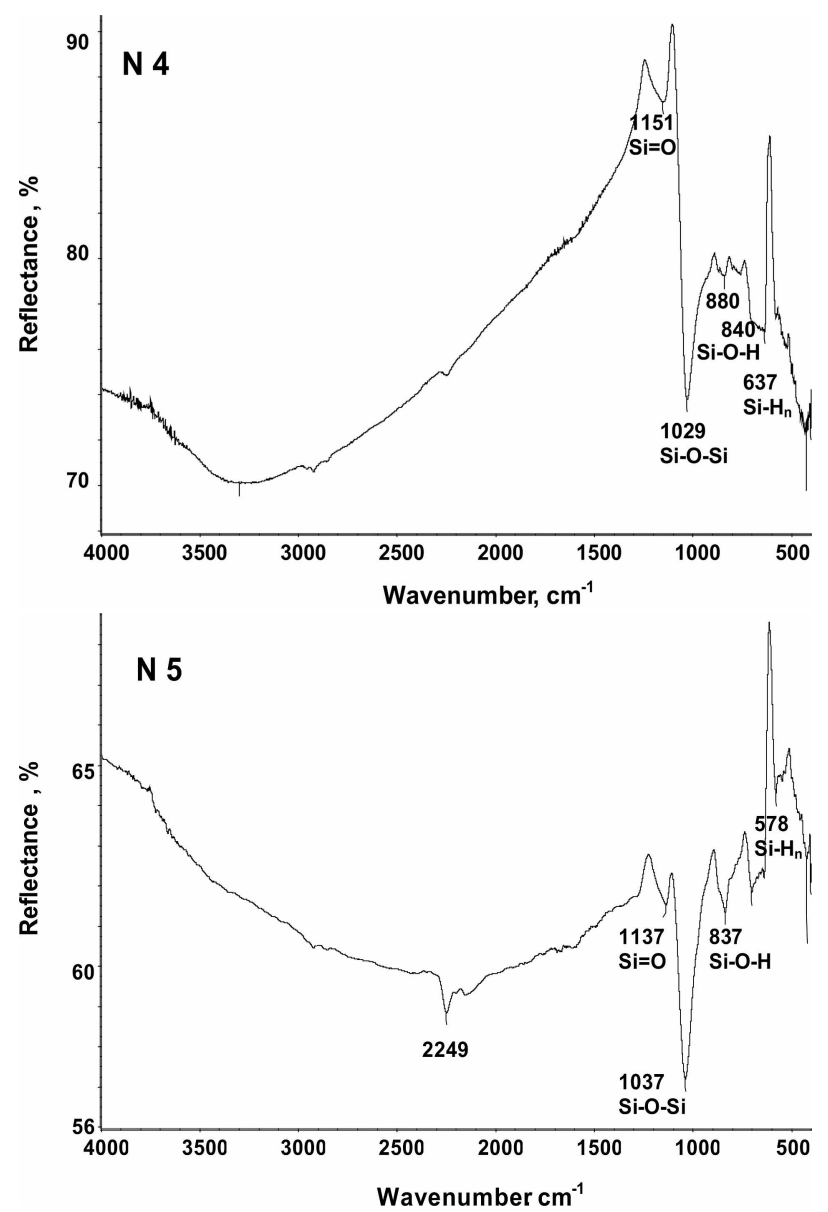

Fig. 4. FTIR spectra of porous Si structures produced varying fabrication parameters. Fabrication parameters of samples are provided in Table 1. 

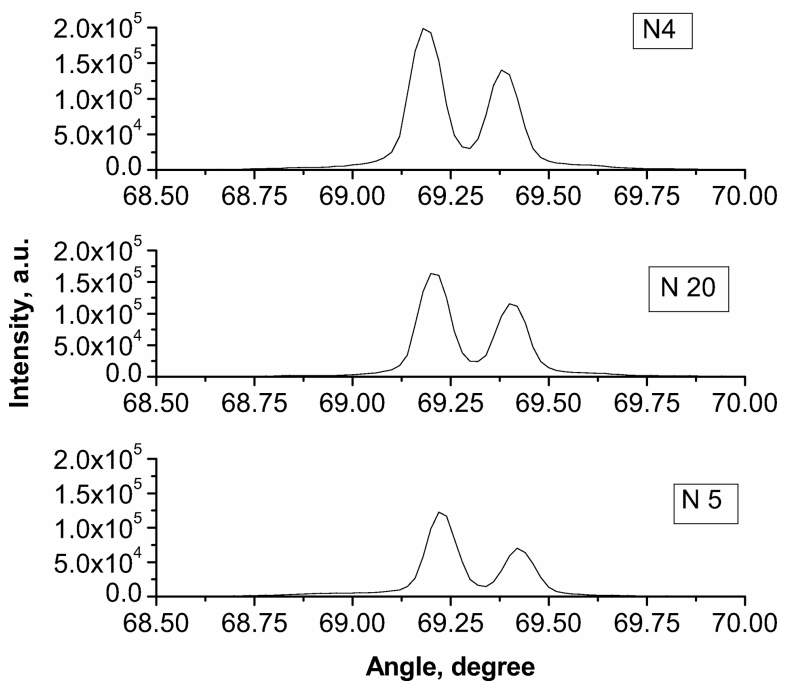

Fig. 5. XRD spectra of samples fabricated keeping the same 4:1 concentration of $\mathrm{HF} / \mathrm{HNO}_{3}$ in the mixture but using different etching time.

to the growth of small diameter pores into the depth. The FTIR spectrum of $N 8$ sample, produced at the acid ratio 1:1, is provided in Fig. 4 for comparison.

$\mathrm{X}$-ray diffraction measurements were used to confirm the presence of Si crystallite clusters in the fabricated porous silicon structures as indicated in SEM images. Segments of XRD spectra corresponding to porous structures produced under different fabrication conditions are presented in Fig. 5.

The X-ray diffraction patterns show two well-resolved peaks, corresponding to the lattice parameter of the porous Si (400) layer (left) and the Si (100) substrate (right) indicating that the porous Si has the same crystalline structure as the bulk $\mathrm{Si}$, but with larger lattice parameters [10, 11]. The intensity of the porous Si peak (400) was growing with the etching time and porosity of layers. The angular distance $\Delta \bar{\omega}$ between the Bragg peaks of porous silicon and silicon substrate is related to the lattice mismatch $\Delta a / a$ :

$$
\frac{\Delta a}{a}=-\frac{\Delta \bar{\omega}}{\tan \bar{\omega}_{\mathrm{B}}}
$$

where $\bar{\omega}_{\mathrm{B}}$ is the silicon substrate peak position [9]. The lattice mismatch $\Delta a / a$, given by peak separation, increases with porosity and is about $2.5 \cdot 10^{-3}$. Small lattice distortions in crystalline planes are increasing when the thickness of the porous Si layer increases and depend on the layer formation parameters. It is well known [6, 12] that the XRD peak width depends on the average crystallite size which may be evaluated using Scherrer's formula

$$
d=\frac{k \lambda}{\beta \cos \theta},
$$

where $d$ is a crystallite size, $\lambda$ is X-ray wavelength, $\beta$ is FWHM of peak, $\theta$ is Bragg angle, and $k$ is Scherrer constant, which depends on the crystallite shape and diffraction line index. Evaluated crystallite size (Table 2) varied in the range of 3.1-3.8 $\mathrm{nm}$ and was dependent on vapour phase etching parameters. A decrease in the average crystallite size indicated an increase in porosity. Clusters of small-sized crystallites were characteristic of both mesoporous (pore size $>50 \mathrm{~nm}$ ) and nanoporous silicon.

The non-destructive Raman scattering method provides additional information about the structure of fabricated porous silicon layers. The Raman spectra can be decomposed into several bands corresponding to different organized structures. Information about nanocrystallite size can be obtained from the corresponding peak shape and peak position. The finite size effects, which destroy the full translational symmetry of the material, result in a low-frequency asymmetric broadening and red shift of the Raman band.

The fitting of the Raman bands was achieved by the Gaussian convolution of the obtained Raman spectra of samples as shown in Fig. 6.

The performed procedure resulted in identification of three main peaks in $\mathrm{Si}$ structures, corresponding to crystalline (c-Si, peak 3), amorphous (a-Si, peak 1 ), and porous (p-Si, peak 2) silicon. Small c-Si peaks (Fig. 6, peak 3) found at around $520 \mathrm{~cm}^{-1}$ are associated with the longitudinal optical mode (LO) in the crystalline silicon. The observed Raman spectra broadening corresponding to the first split of the spectral peak at 466$489 \mathrm{~cm}^{-1}$ corresponded to the transverse optical (TO) mode in the amorphous silicon. The peak half width varied from 56 to $82 \mathrm{~cm}^{-1}$. Both peaks (c-Si and a-Si) could be found in the initial unetched samples. One more peak at $501-515 \mathrm{~cm}^{-1}$ with $71-92 \mathrm{~cm}^{-1}$ FWHM was found in the Raman spectra of the etched samples. Depending on the technological parameters of sample fabrication it was shifted towards higher excitation energies, i. e. to a porous silicon peak. An intensive and broad-contour Raman peak with a typical continuum in the lower energy range corresponds to the formation of a nanoporous structure [13, 14]. It should be noted that the tendency of rising in Raman spectra indicated the existence of silicon oxides, which was confirmed by IR spectroscopy. A small shift of the Raman peak corresponding to the porous $\mathrm{Si}$, as compared to the $\mathrm{Ra}$ man peak of crystalline Si structure, indicates the presence of different-sized crystallites and formation of the mesoporous structure. The increased concentration of $\mathrm{HF}$ in the acid mixture (Raman peak at $505 \mathrm{~cm}^{-1}$ for 

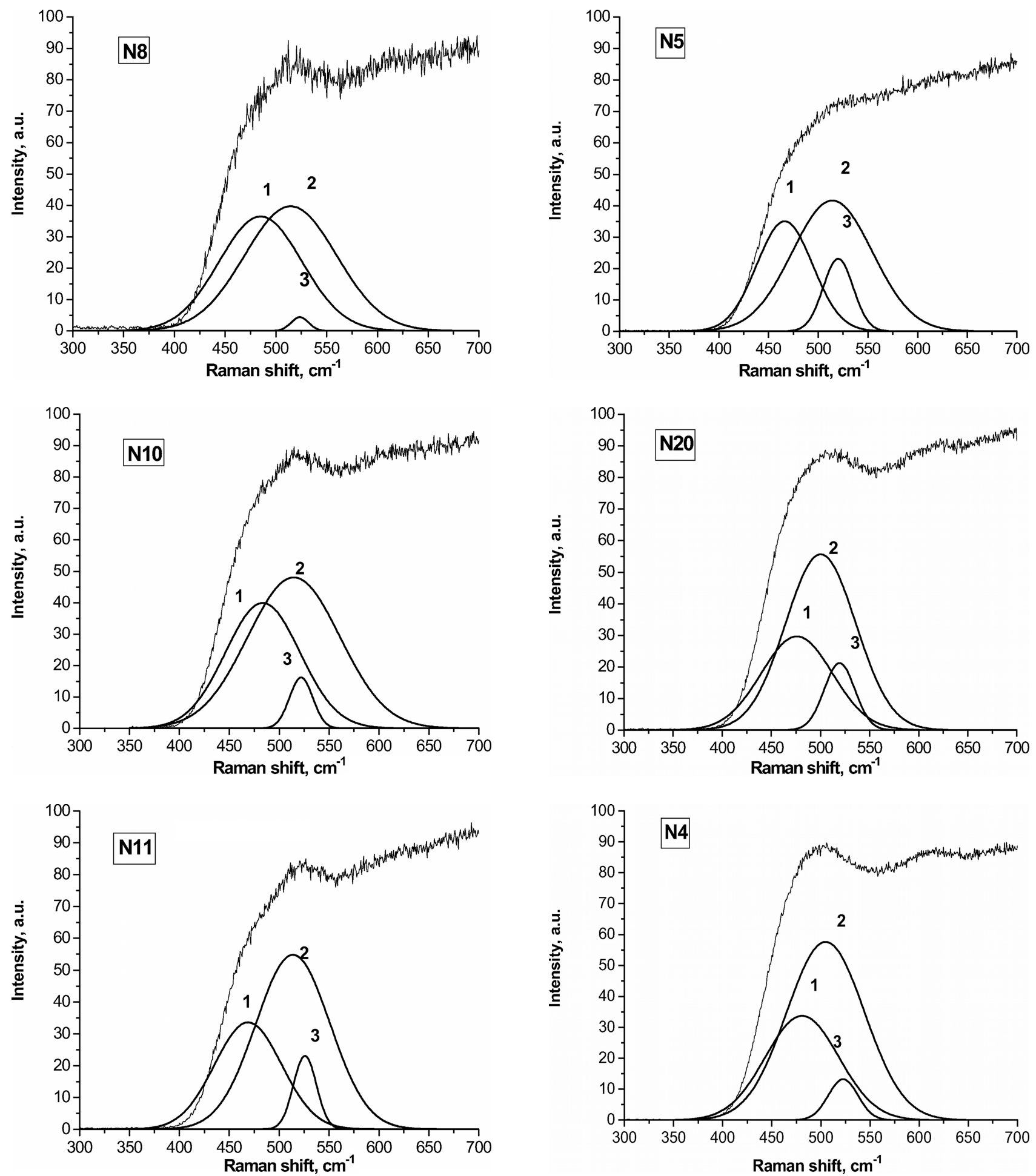

Fig. 6. Raman spectra of experimental samples including Gaussian convolution curves. Peak 1 corresponds to the amorphous Si, peak 2 corresponds to the porous $\mathrm{Si}$, and peak 3 corresponds to the crystalline $\mathrm{Si}$. 
N4) clearly indicates a nanocrystalline structure. Information about nanocrystallite size can be obtained from the shape and peak position of the first-order Raman scattering band. Crystallite size was calculated according to the Cardona equation [15]:

$$
d=\frac{2 \pi \sqrt{\frac{B}{\Delta \bar{\omega}}}}{10}[\mathrm{~nm}],
$$

where $B=224 \mathrm{~cm}^{-1}, \Delta \bar{\omega}$ is the Raman shift related to the c-Si peak. Crystallite size was found to vary between 3.1 and $4.0 \mathrm{~nm}$ (Table 2). An analysis of the spectra according to the model of phonon confinement in silicon nanocrystals [16] has indicated that the nanocrystallites in nanoporous silicon are best approximated by spheres $2-4 \mathrm{~mm}$ in diameter.

The luminescent properties of nanostructured materials depend on the size and shape of nanoparticles. If the size of crystallites is $<5 \mathrm{~nm}$, luminescence is caused by the space quantification effects [17]. For this reason, the PL spectra of porous $\mathrm{Si}$ samples were measured (Fig. 7) and a correlation of porous structure fabrication parameters with particle size and luminescence efficiency was investigated. Measurements were performed at four different temperatures: $3.6,35,77$, and $300 \mathrm{~K}$ (room temperature) with the aim to assess the thermal aspect of luminescence in porous $\mathrm{Si}$.

The PL peak position was found to depend on the temperature and fabrication parameters of porous structures. The intensity of photoluminescence spectra was comparable in all samples. Luminescence bands were not symmetric and had a higher intensity in the shortwave range. This feature corresponds to the relatively high content of nanocrystallites in the experimental samples. A small blue shift of the PL peak, indicating an increased porosity, was observed in porous $\mathrm{Si}$ samples at all temperatures when the $\mathrm{HNO}_{3}$ concentration in the $\mathrm{HF} / \mathrm{HNO}_{3}$ acid mixture or the etching time keeping a constant ratio of acid concentrations was increased. Samples of the same group produced at a relatively high $\mathrm{HF}$ concentration in the $\mathrm{HF} / \mathrm{HNO}_{3}$ acid mixture (4:1) indicated a PL peak shift towards lower energies at room temperature as compared to those measured at lower temperatures $(T \leq 77 \mathrm{~K})$ as shown in Fig. 7 (samples N5, N2O, N4). The increased concentration of $\mathrm{HNO}_{3}$ in the mixture of acids and the constant etching time of samples were responsible for a significant shift of the PL peak to the higher energies at room temperature (Fig. 7, samples $N 8$ and N11). The difference in the spectral positions of PL bands in porous silicon might also be caused by the different composi- tions of silicon oxides on the Si surface, where the corresponding radiation defects are localized [8, 11, 18]. The obtained differences could be explained by carrier recombination processes in nanocrystalline structures and phonon contribution to the radiant processes.

It is known [19] that the PL peak of crystalline Si corresponds to the energy of the forbidden gap. The PL peak at the quantum energy $h \nu=1.13 \mathrm{eV}$ was estimated for crystalline Si targets used in the fabrication of experimental samples. According to Ref. [8], the PL peak has to be shifted towards higher energies by $>0.4 \mathrm{eV}$ in nanoporous structures. Vapour etched structures are characterized by crystallites of different size and shape, which additionally contribute to the shift of the spectrum band towards higher energies [20]. Therefore, a slightly higher $(0.5-0.7 \mathrm{eV})$ "blue shift" of the peak in PL spectra, as compared with electrochemically produced samples, was observed in all study samples. Phonon spectra are dependent on the regularity of the micro structure and reflect the information about the pore distribution and density in a sample as well as about the size and shape of nanocrystallites in the structure [21]. Upon evaluating the shift of the PL peak it was possible to calculate the nanocrystallite size according to the empirical formula $[15,22,23]$

$$
E=E_{0}+\frac{88.34}{d^{1.37}},
$$

where $E_{0}$ is the energy of the forbidden gap in crystalline $\mathrm{Si}, E$ is the energy corresponding to the peak position in PL spectrum, $d$ is the size of a nanocrystallite.

Crystallite size was calculated for two temperatures, 77 and $300 \mathrm{~K}$, having in mind possible oxidation of the pore surface at the room temperature. It is to point out that crystallites of very small diameters should also exist, but they are not able to luminesce at the applied excitation wavelength $(488 \mathrm{~nm})$. Therefore, only mean diameter of luminescent crystallites was determined [23].

Results of crystallite size calculations using different methods are presented in Table 2.

Calculations have shown that the PL peak position is tightly related to the morphology of the study structure: a higher PL peak energy corresponds to the porous structure with clusters of 3.4-3.8 nm sized nanocrystallites. A low-intensity photoluminescence spectrum, the PL peak shifted towards lower energies, and largesized crystallites are the main characteristics of a mesoporous structure. At the size of crystallites $d>4.0 \mathrm{~nm}$, the PL intensity increases very slowly due to luminescence defects caused by an increased content of oxides 

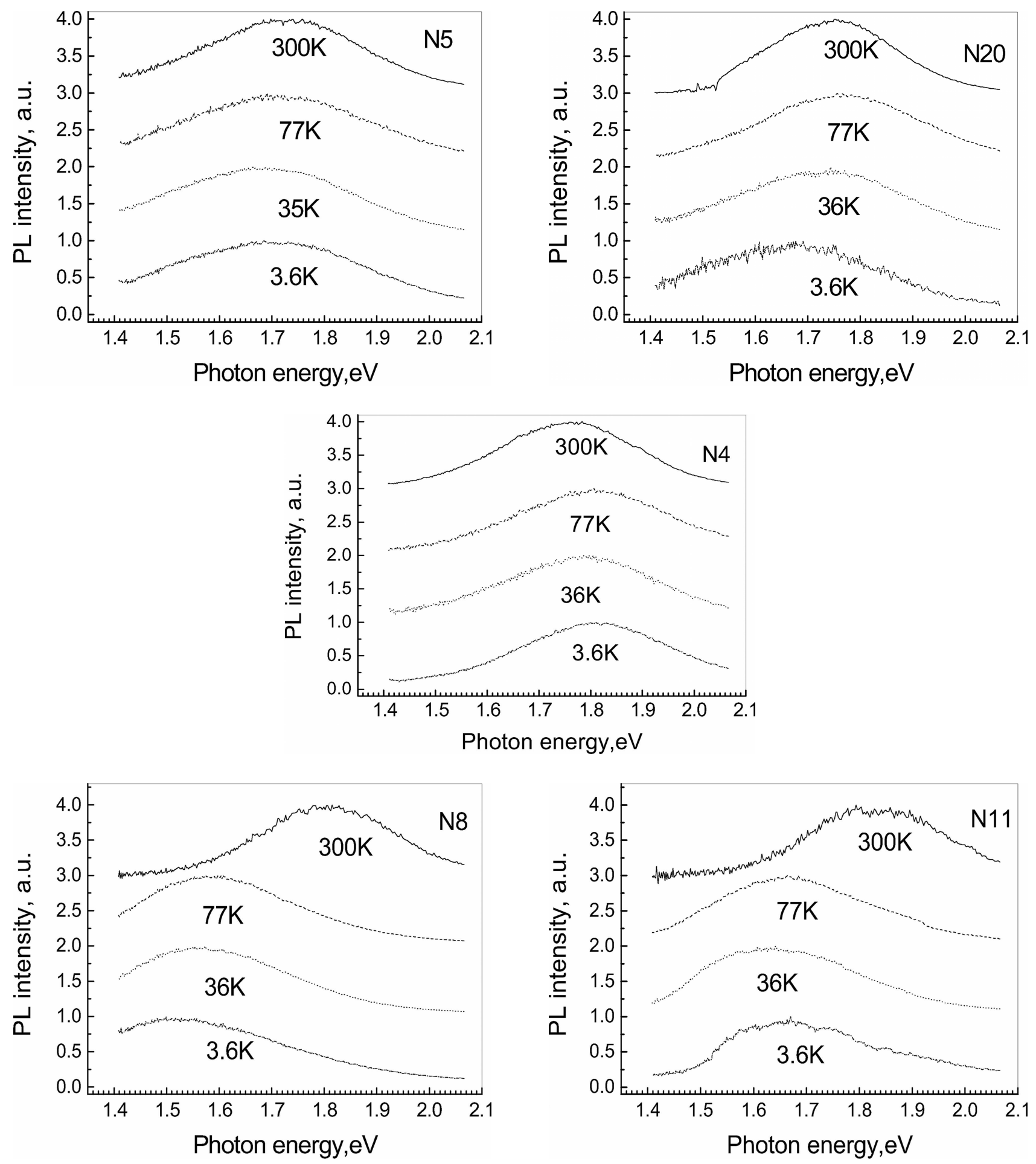

Fig. 7. Temperature dependent PL spectra of porous structures produced by Si etching in the vapour phase of $\mathrm{HF} / \mathrm{HNO}_{3}$ acid mixture.

in a sample. This is relevant to the sample $N 8$ and agrees well with results by von Behren et al. [24]. Due to the oxidation effects, which could prevail over pore growth processes if the concentration of HF in the acids mixture is relatively low, almost no changes in the morphology and only small variations in the crystallite size of the porous structures $N 8, N 11$ were observed while performing PL measurements at room temperature. More reliable results were obtained when performing PL measurements at the liquid nitrogen temperature $(77 \mathrm{~K})$. These results were comparable to those obtained using experimental data of XRD analysis and Raman spectroscopy. Small differences in nanocrystallite size were possible, since Scherrer's formula does 
Table 2. Crystallite size in the porous Si structures.

\begin{tabular}{|c|c|c|c|c|c|c|c|}
\hline \multirow[b]{2}{*}{ Sample } & \multirow[b]{2}{*}{$\mathrm{HF} / \mathrm{HNO}_{3}$} & \multirow{2}{*}{$\begin{array}{l}\text { Etching } \\
\text { time, } \mathrm{h}\end{array}$} & \multicolumn{4}{|c|}{$\mathrm{d}, \mathrm{nm}$} & \multirow{2}{*}{$\begin{array}{c}\text { Porosity, } \\
\%\end{array}$} \\
\hline & & & XRD & Raman & $\begin{array}{c}\text { PL, } \\
300 \mathrm{~K}\end{array}$ & $\begin{array}{l}\text { PL, } \\
77 \mathrm{~K}\end{array}$ & \\
\hline N5 & $4: 1$ & 24 & 3.3 & 3.7 & 3.8 & 3.8 & 66.8 \\
\hline$N 20$ & $4: 1$ & 48 & 3.2 & 3.5 & 3.7 & 3.6 & 83.6 \\
\hline N4 & $4: 1$ & 60 & 3.1 & 3.1 & 3.6 & 3.4 & 86.7 \\
\hline$N 11$ & $1: 6$ & 24 & 3.6 & 3.5 & 3.4 & 3.6 & 83.6 \\
\hline N10 & $1: 2$ & 24 & 3.4 & 3.6 & 3.4 & 4.0 & 75.3 \\
\hline N8 & $1: 1$ & 24 & 3.8 & 4.0 & 3.5 & 4.3 & 61.4 \\
\hline
\end{tabular}

not account for the stress induced during the formation of porous structures.

Generally, increased porosity causes a PL peak shift to the higher energies. The decreased crystallite size in irradiated samples is closely related to the increased porosity of the porous structures due to pore growth. This statement agrees well with the increased intensity of the Raman spectra. According to Kompan et al. [25] and Kaabi et al. [1] it corresponds to the more intensive light penetration into the samples due to the decreased material density. However, according to our estimates (Table 2), exceptions are possible when two samples prepared in different conditions have the same porosity (samples N11 and N2O). This may be related to the thickness of the $N 11$ porous layer, which is almost twice as thick as the samples from the same group.

\section{Conclusions}

Electrochemical etching is the most effective method for the production of regular porous silicon structures used in electronic devices of different applications. However this is not the best way to form porous silicon for solar cells or to produce large area photodectors and other devices. The vapour etching method is relatively simple as compared with the electrochemical method. Using this technique a pyramid-like hillock porous silicon surface, essentially formed of interconnected cluster structure, is produced. It is easy to coat a thin, rough, and homogenous surface layer with an active metal and to modify its reflectance and photoluminescence properties.

The surface morphology and porosity of silicon layers produced using chemical etching in the vapour phase of an $\mathrm{HF} / \mathrm{HNO}_{3}$ acid mixture depends on the technological parameters of its fabrication. The present study has shown that vapour etching is responsible for the growth of differently sized and shaped pores randomly distributed in the fabricated inhomogeneous porous Si layers. Lower HF concentrations in the
$\mathrm{HF} / \mathrm{HNO}_{3}$ mixture supported pore growth into the depth, and the prolonged etching time while keeping constant the relatively high HF concentration in the acid mixture was responsible for the increased active surface of the pores. The presence of crystalline, amorphous, and porous $\mathrm{Si}$ in the produced porous layers was shown by the results of FTIR and Raman spectrometry. The presence of clusters of different size nanocystallites was indicated in the skeleton of porous layers. Applying different methods based on experimental XRD, Raman, and photoluminescence measurements the crystallite size was deduced to be $3.1-4.3 \mathrm{~nm}$. It was related to the porosity of fabricated layers: the porosity of a layer was lower when the content of $\mathrm{HNO}_{3}$ in the acid mixture was higher, indicating a formation of mesoporous structures. An increasing porosity was observed upon increasing the etching time of samples when a relatively high concentration of $\mathrm{HF}$ in the $\mathrm{HF} / \mathrm{HNO}_{3}$ mixture was kept constant during the lengthy fabrication process. It has been shown that by varying the technological parameters and conditions of the vapour phase etching process it is possible to control porosity and crystallite size in the fabricated porous silicon films and to produce Si nanostructures with an enhanced active surface layer.

\section{References}

[1] H. Kaabi, N. Mliki, M. Cheynet, W. Saikaly, O. Gilbert, B. Bessaïs, B. Yangui, and A. Charaï, Structural and optical properties of vapour-etching based porous silicon, Cryst. Res. Tech. 41(2), 154-162 (2006).

[2] M. Saadoun, N. Mliki, H. Kaabi, K. Daoudi, B. Bessaïs, H. Ezzaouia, and R. Bennaceur, Vapouretching-based porous silicon: a new approach, Thin Solid Films 405(1-2), 29-34 (2002).

[3] S. Boughaba and K. Wang, Fabrication of porous silicon using a gas etching method, Thin Solid Films 497(1-2), 83-89 (2006).

[4] M. Ben Rabha, M. Saadoun, M.F. Boujmil, B. Bessaïs, H. Ezzaouia, and R. Bennaceur, Application of the 
chemical vapor-etching in polycrystalline silicon solar cells, Appl. Surf. Sci. 252(2), 488-493 (2005).

[5] A. Ben Jaballah, M. Saadoun, A. Hajji, H. Ezzaouia, and B. Bessaïs, Silicon dissolution regimes from chemical vapour etching: from porous structures to silicon grooving, Appl. Surf. Sci. 238(1-4), 199-203 (2004).

[6] B.E. Warren, X-Rays Diffraction (Dover Publications, Inc., NY, 1990).

[7] S. Stolyara, S. Weiss, M. Levy, and Y. Nemirovsky, New type of dual macro and nano fractal structure of reaction induced vapor phase stain etched porous silicon, Phys. Status Solidi 4(6), 2054-2058 (2007).

[8] S. Aouida, M. Saadoun, K. Ben Saad, and B. Bessaïs, Structural and luminescence properties of vapouretched porous silicon and related compounds, Phys. Status Solidi 2(9), 3409-3413 (2005).

[9] R. Herino, G. Bomchil, K. Barla, and C. Bertrand, Porosity and pore size distributions of porous silicon layers, J. Electrochem. Soc. 134(8), 1994-2000 (1987).

[10] V. Chamard, S. Setzu, and R. Romestain, Light assisted formation of porous silicon investigated by X-ray diffraction and reflectivity, Appl. Surf. Sci. 191(1-4), 319-327 (2002).

[11] Y. Zhao, D. Li, W. Sang, D. Yang, and M. Jiang, The influence of microstructure on optical properties of porous silicon, Solid State Electron. 51(5), 678-682 (2007).

[12] S.V. Bhoraskar, T. Bhave, and T.A. Railkar, Crystallitesize-dependent characteristics of porous silicon, Bull. Mater. Sci. 17(5), 523-531 (1994).

[13] M.G. Lisachenko, E.A. Konstantinov, V.Yu. Timoshenko, and P.K. Kashkarov, Special features of recombination of nonequilibrium charge carriers in porous silicon with different nanostructure morphologies, Semiconductors 36(3), 325-329 (2002).

[14] B. Bulakh, N. Korsunska, L. Khomenkova, T. Stara, Ye. Venger, T. Kryshtab, and A. Kryvko, Structural and luminescent characteristics of macro porous silicon, J. Mater. Sci. Mater. Electron. 20, 226-229 (2009).

[15] Z.C. Feng and R. Tsu, Porous Silicon (World Scientific, Singapore, 1994).
[16] I.H. Cambell and P.M. Fauchet, The effects of microcrystal size and shape on the one phonon Raman spectra of crystalline semiconductors, Solid State Commun. 58(10), 739-741 (1986).

[17] L.T. Canhamm, Silicon quantum wire array fabrication by electrochemical and chemical dissolution of wafers, Appl. Phys. Lett. 57(10), 1046-1048 (1990).

[18] T.V. Torchynska, J. Aguilar-Hernandez, A.I. Diaz Cano, F.G. Becerril-Espinoza, Y. Goldstein, A. Many, J. Jedrzejewskii, L.Yu. Khomenkova, B.M. Bulakh, and V. Scherbina, Photoluminescence and its excitation mechanisms in Si wires and dots, Phys. Status Solidi 197(2), 382-387 (2003).

[19] L. Liu, C.S. Jayanthi, and S.-Y. Wu, Factors responsible for the stability and the existence of a clean energy gap of a silicon nanocluster, J. Appl. Phys. 90(8), 41434151 (2001).

[20] B. Bessam, O. Ben Younes, H. Ezzaouia, N. Mliki, M.F. Boujmil, M. Oueslati, and R. Bennaceur, Morphological changes in porous silicon nanostructures: non-conventional photoluminescence shifts and correlation with optical absorption, J. Lumin. 90(3-4), 101109 (2000).

[21] S. Kalem and O. Yavuzcetin, Possibility of fabricating light-emitting porous silicon from gas phase etchants, Opt. Express 6(1), 7-11 (2000).

[22] V. Lehmann, B. Jobst, T. Muschik, A. Kux, and V. Petrova-Koch, Correlation between optical properties and crystallite size in porous silicon, Jpn. J. Appl. Phys. 32, 2095-2099 (1993).

[23] V. Agarwal, R.M. Mehra, and P.C. Mathur, Analysis of the broadening of photoluminescence spectra in porous silicon as a function of growth parameters, Thin Solid Films 358(1-2), 196-201 (2000).

[24] J. von Behren, M. Wolkin-Vakrat, J. Jorne, and P.M. Fauchet, Correlation of photoluminescence and bandgap energies with nanocrystal sizes in porous silicon, J. Porous Mater. 7, 81-84 (2000).

[25] M.E. Kompan, I.I. Novak, V.B. Kulik, and N.A. Kamakova, Enhancement of Raman scattering intensity in porous silicon, Phys. Solid State 41(7), 1207-1209 (1999). 


\title{
ĖSDINIMO GARŲ FAZĖJE İTAKA FORMUOJAMO PORE்TOJO SILICIO PAVIRŠIAUS MORFOLOGIJAI IR SANDARAI
}

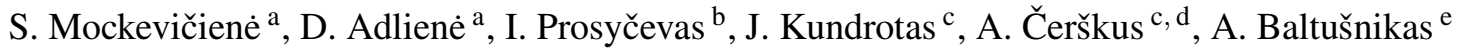 \\ ${ }^{a}$ Kauno technologijos universiteto Fizikos katedra, Kaunas, Lietuva \\ ${ }^{\mathrm{b}}$ Kauno technologijos universiteto Medžiagotyros institutas, Kaunas, Lietuva \\ ${ }^{\mathrm{c}}$ Fiziniu ir technologijos mokslu centro Puslaidininkiu fizikos institutas, Vilnius, Lietuva \\ ${ }^{\mathrm{d}}$ Vilniaus pedagoginis universitetas, Vilnius, Lietuva \\ ${ }^{\mathrm{e}}$ Lietuvos energetikos institutas, Kaunas, Lietuva
}

\section{Santrauka}

Analizuota porètojo silicio, suformuoto naudojant cheminio èsdinimo rūgščiu $\mathrm{HF} / \mathrm{HNO}_{3}$ garų fazejje metodą, sandara ir savybės. Keičiant ėsdinimo proceso parametrus, suformuoti ivvairaus porètumo sluoksniai, besiskiriantys porų forma ir dydžiu bei aktyviuoju paviršiaus plotu. Porétojo Si sluoksnių sandara ir savybės tirtos Rentgeno difrakcijos, Ramano spektroskopijos, infraraudonuju spinduliu spektrometrijos ir fotoliuminescencinès spektroskopijos metodais. Sluoksnių vaizdinimui, taip pat jų morfologijai tirti nau- dotas skenuojantis elektroninis mikroskopas. Vertinant sluoksniu porètumą, panaudoti optinės elipsometrijos metodu nustatyti eksperimentinių darinių lūžio rodikliai. Vertinant kristalitų dydị, buvo atsižvelgiama i porètojo, kristalinio ir amorfinio silicio sandus eksperimentiuose dariniuose. Nustatyta, kad kristalitu dydis tirtuose poretuose sluoksniuose kito nuo 3,1 iki 4,3 nm, o skirtingu bandinių porètumas kito nuo 61,4 iki $86,7 \%$. Remiantis gautais rezultatais, aptartas mezoporetujų darinių su nanokristalitais formavimas, kontroliuojant cheminio ėsdinimo garų fazeje parametrus. 